\title{
Processes of middle-class reproduction in a graduate employment scheme
}

\author{
Sarah Smart with Merryn Hutchings, Uvanney Maylor, Heather Mendick and Ian Menter
}

IPSE, London Metropolitan University, London, UK

Teach First is an educational charity that places graduates to teach in 'challenging' schools for two years. It is marketed as an opportunity to develop employability while 'making a difference'. In this paper, I examine the process of class reproduction occurring in this graduate employment scheme through examining the discourses used in Teach First marketing and by Teach First participants. I begin by arguing that the Teach First participants interviewed as part of an evaluation were predominantly middle-class, and possessed social and cultural capital which had facilitated their access to the Teach First scheme. I then illustrate three processes of middle-class reproduction within Teach First. The first is the accumulation by participants of additional social and cultural capital. The second is the reproduction of middle-class values and stereotypes of the workingclass other, and the third is the obscuring of middle-class advantage through discourses of 'natural ability'. I conclude that although well-intentioned Teach First participants worked extremely hard to combat educational disadvantage, their actions were twisted by class forces, and resulted in the reproduction of middle-class privilege.

With the expansion of higher education, and increasing competition between graduates in the labour market (Tomlinson 2008), accessing a high-quality graduate training scheme is an increasingly important step in a career trajectory. This paper uses the example of Teach First, a graduate recruiter, to illustrate how accessing a scheme of this kind can act as part of the process of middle-class reproduction. Teach First recruited and placed its first intake in the summer of 2003. It is a training programme for graduates who commit themselves to teaching for two years in challenging secondary schools. Participants undergo both teacher training (in the first year) and a programme of leadership training (starting in the summer term of the first year and extending into the second year). For the first three years, the programme operated only in London; there are now Teach First participants working in schools in London, the North West and the Midlands.

Teach First was created in response to a report from management consultant McKinsey, suggesting that 'Even taking deprivation levels into account, “excellent” teachers can increase the percentage of pupils who gain 5+ A*_ C GCSEs by 40\% over what would normally be expected' (Teach First website). This report recommended a programme that 'targeted top graduates, using the support of businesses and education leaders to bring additional excellent teachers into challenging schools for two years'. Teach First is targeted at new graduates who would not otherwise have become teachers, and it is anticipated and accepted that many of them will go on to careers in other sectors (hence the name, Teach First). To date, around 50\% of participants have stayed for a third year (DCSF 2008), and in the first cohort $40 \%$ of those who stayed for a third year anticipated a long career in teaching (Hutchings et al. 2006). Teach First is supported by large corporations, small businesses, non-profit organisations, educational institutions and policy groups. Supporters contribute to Teach First participants' development through one-to-one volunteer coaching, summer projects and skills and industry-based training. The Teach First website suggests that this allows supporters to promote their organisation, assess the capability of participants as future employees and fulfil some of their corporate responsibility obligations through supporting challenging schools.

Teach First has been very successful in recruiting high-achieving graduates and positioning itself as a prestigious graduate scheme. In the first year (2003), 1300 people applied for the 250 places available. In the first years, the majority of participants on the programme had degrees from Russell Group universities (83\% in 2003; 74\% in 2004), with particularly large groups from Oxford and Cambridge (one third of the first cohort, and a quarter of the second cohort). The vast majority of the 2003 and 3004 cohorts had upper second-class or first-class degrees (Hutchings et al. 2006). In 2007, Teach First reached fourteenth position on The Times' list of the top 100 graduate employers. 1

In this paper, I am using Teach First as a case study of processes and discourses that exist within the school system and graduate labour market more generally; the processes that I describe are not unique to Teach First, nor are they new. Teach First is perhaps in some ways unusual because it was marketed as an opportunity that combined altruism and ambition. Those who run Teach First, and all of the participants interviewed as part of the evaluation, had a desire to improve challenging schools. Participants often worked very long hours and went out of their way to provide new/additional extracurricular activities in their schools. Many participants gave examples of pupils with whom they had formed particularly good relationships, or who had done unexpectedly well in exams. Thus at the level of individual pupils and initiatives in school, participants identified many positive differences that had come about because of Teach First. These aspects of Teach First have been written about elsewhere (Hutchings et al. 2006; Ofsted 2008) and are not the focus of this paper. I wish to focus attention here on the way in which participants' class status made it possible for them to combine this altruism with ambition, and how they were engaged in a process of middle-class reproduction. I begin by outlining the data on which I am drawing and on my theoretical approach.

\section{Methodology}


As part of an evaluation of the first two years of Teach First funded by the Teacher Training Agency (TTA)2 (Hutchings et al. 2006), the evaluation team observed recruitment, training and other events, conducted questionnaires of all Teach First participants3 and interviewed Teach First employees, stakeholders, tutors, participants (from the first and second cohorts) and mentors. Additionally, members of the evaluation team conducted an additional evaluation funded by the Gatsby Trust of Teach First activities funded by the Trust (Mendick, Hutchings, and Steensborg 2007). This involved additional interviews with participants and Teach First staff and observations of events. In total, individual interviews were conducted with more than 60 participants, of whom the majority were interviewed twice, and more than half were interviewed at three points during their time in Teach First. Interviews focussed on the innovative aspects of Teach First and covered stakeholder and participants' experiences of recruitment, training, teaching, Teach First activities, plans for the future and their views about Teach First. All interviews were fully transcribed and analysed using NVivo. This paper draws on information provided on the Teach First website and interviews with Teach First staff and participants (all of the names given are pseudonyms) conducted as part of the additional evaluation for the Gatsby Trust. In some places, questionnaire and interview data reported in the TTA evaluation is given to support these sources (Hutchings et al. 2006).

My aim in this analysis has been to explore what these texts tell us about the positions from which the authors are speaking, their explanations of their experiences on Teach First and their construction of the social world. I began by examining the claims made in Teach First publicity about the benefits to participants of taking part in Teach First, and the role of the challenging school in these benefits, examining the way Teach First constructed participants and schools. I then looked at participant narratives, to compare the way in which they positioned themselves in relation to Teach First, the challenging schools and their pupils. This led to my focus on social, cultural and symbolic capital and class position.

\section{Theoretical perspectives}

My argument centres around the role of Teach First in the reproduction of class hierarchies. Social class is a contested concept. The defining of class through relationship to the means of production has been complicated by changes in social structure and the individualisation of society, which has led some to argue for 'the death of class' (Pakulski and Waters 1996). However, proponents of class analysis argue that class remains a salient feature in society, not only as an economic marker, but a symbolic and cultural one (Lawler 2005).

Cultural analysts of class (e.g. Ball 2003; Skeggs 2004; Lawler 2005; Reay 2006) understand class as a social process that encompasses complex social and psychological dispositions that inform everyday practice. While actors do not often refer directly to class position, ideas of class colour everyday interactions and decisions in complex ways (e.g. Reay 1997, 1999, 2005; Reay et al. 2001; Ball 2003). The uneven distribution of economic, social and cultural capital is a key aspect of class, but it is the way in which different capitals are classified, valued and judged that produces the lived experience of class. The significance of class is that it offers us positions to inhabit and representations through which we can know ourselves and others (Skeggs 1997b). I will show how Teach First participants positioned themselves as middle-class, and how participation in Teach First both required and generated social and economic capital. I also illustrate how participants used classed narratives to describe the schools where they taught and the families of the children they taught.

Some cultural theorists have looked at differences within class groups, and the production of boundaries within the middle-class as well as between the middle-class and their class 'others' (e.g. Ball et al. 2004). I would agree that the terms 'middleclass' and 'working-class' simplify the complex divisions of status and hierarchy that exist in modern society. However, the terms allow a focus on class conflict, the different access to material and cultural resources between classes, and the associated 'structures of feeling' that create insecurity, self-doubt, resentment and anger for those who are represented and positioned as working-class (Skeggs 1997a). For clarity, I have in this paper focussed on the contrast between middle- and working-class. I am aware that the effects of class on material and affective/relational outcomes are not independent of other variables, but are cross-cut by other aspects of social inequality such as gender, dis/ability, sexuality and so on (e.g. Walkerdine, Lucey, and Melody 2001). In particular, there were complex issues around race and ethnicity in these data. However, because all of the Teach First participants interviewed were middle-class, while almost all of their pupils were working-class, the issue of class was particularly salient, and is the focus of this paper.

The next section of the paper explores some of the representations of Teach First on their website and in interviews with participants, and the insights this gives into the class position of Teach First participants. The sections that follow illustrate three processes of middle-class reproduction within Teach First: the accumulation by participants of additional social and cultural capital, the reproduction of middle-class values and stereotypes of the working-class other, and the obscuring of middle-class advantage through discourses of 'natural ability'.

Teach First participants positioned themselves as middle-class 
I have argued above that class offers individuals positions to inhabit. The positions inhabited by Teach First participants were both explicitly and implicitly middle-class. Participants were not asked directly about their class position, although a small number explicitly referred to themselves as middle-class, usually when they were referring to the contrast between their experience and that of their pupils:

I went to a middle-class suburban comprehensive so maybe it's very different. (Thomas)

I went to school in [location]. It was very white and middle-class. (Gareth)

I was quite a sheltered middle-class girl ... Some of the problems these kids have blows your mind. (Jaya)

While participants only rarely described themselves as middle-class, other signifiers of class position were common to the talk of most interviewees. Here I examine two: the distinctions participants made between 'people like us' and 'people unlike us', found in the majority of accounts; and the way participants talked about shaping and managing the self, which was common to all participants.

Reay observes that while the mothers in her study did not mention social class, they 'continually used distinctions of "people like us" and "people unlike us" which drew on class as well as racialized imagery in order to differentiate between themselves and others' $(1999,96)$. In our interviews, participants tended to describe other Teach First participants as similar to them in many ways, and pupils and their families as different.

When interviewees spoke about other participants they used adjectives such as like-minded, high quality, ambitious and teachable. They described quickly becoming friends, and supporting each other in school. One described the other participants as 'bright, sparkly people':

I don't think every single one of [the Teach First people] is an exceptional person but there are lots of bright, sparkly people that are interested in education. And so it was nice to get in a group like that. (Paul)

One participant compared the kind of people that she met on Teach First with the kind of people she had met at other assessment days, and concluded that 'most of the people [at the Teach First interview] were quite similar people with similar kinds of ideas and quite interesting and different kinds of backgrounds and stuff and so that was really nice'. This participant seemed to be identifying Teach First participants as coming from a particular middle-class fraction, as she was comparing Teach First participants with applicants for banking and finance jobs. In comparison to the banking and finance candidates, she described Teach First participants as similar and interesting, with enough differences in background to be 'nice'.

In contrast, participants described their schools, pupils and the families of their pupils as 'not like them'. At the beginning of the programme, a few participants indicated that they expected to experience a different way of life, or social environment by doing Teach First:

I wanted to teach in a challenging school, somewhere that was challenging and somewhere, you know, I would be opened up to a different environment to my own upbringing I suppose. (Brian)

Brian is saying that the challenging school will be a different environment to the one where he was brought up, but something he wants to experience and be 'opened up to'. Some participants elaborated on the differences between their upbringing and their school placement:

(And how does it compare to your schooling?) So totally different that I don't even reflect on the comparison. I meant it's just ... it wouldn't enlighten me at all if I compared it so I don't - it's like another planet, it really is. It's as if I've never ... coming in to this school as if I'd never seen a school before. All the previous experience is null and void. (Derek)

I went to a private convent school and it had discipline and it was nothing like this at all. This has been totally different to me and really challenging to me because of some of the behaviour that I've seen. I'm not used to that because I've not been to schools like this before so I'm glad I've come here. (Sarah)

The challenging school is 'another planet' and 'totally different', but somewhere that participants are glad to experience. Several participants commented that although their schools were located in areas of middle-class housing, none of the pupils were from the area:

You've got middle-class suburbs all around, but none of those kids are from ... basically you get everyone's shipped in effectively, there's two bus lines and they come in and just go out like that. (Henry)

Thus Henry positions his pupils as not belonging in the middle-class suburbs all around, but rather being 'shipped in', suggesting that they are working-class, not middle-class.

For Thomas, the 'very middle-class sort of bourgeois comprehensive' where he did his second school placement and 'everything runs like a finely oiled machine' was 'nice but I just felt the kids were boring to be absolutely honest'. He preferred his challenging school because 'I could have an awful lot more fun with some of the students that I teach and I can do things that I would never get away with there'. Thomas is positioning his Teach First school as different to a middle-class, bourgeois comprehensive; the middle-class comprehensive is boring, 
while his school is 'fun' and somewhere that he can 'have a laugh and a joke'.

So, participants tended to position their Teach First schools as different to their own experience, and different to middle-class schools or areas. Participants also tended to speak about their pupils as 'people unlike me'. Many participants described huge differences between their values and those of their pupils:

You probably can imagine teaching people from the working-class, they've got entirely different values from you and sometimes to actually serve them you have to get into their world first which is immensely difficult. It's just not natural for me to think the ways that they think. It’s just opposite almost. (Charles)

It's the fact that you value education, and you value what you are doing, and say somebody else opposite is not valuing it at all, because they don't know how to value it. (Henry)

In this quotation, Charles labels his pupils as working-class (and implicitly himself as middle-class) and explains that it is 'just not natural' for him to think like his workingclass pupils because there is a clash of values. Although Charles is unusual in using the phrase 'working-class' his positioning of his pupils as unlike him and having different values is similar to other participants. In the second quotation, Henry explains that what he finds difficult about Teach First is when a pupil (someone opposite) doesn't value education in the way that he does. Pupils were not only positioned as having different values, but also different kinds of home, different aspirations and different experiences of the world. For example, Claire explains that her pupils 'can't see any way out of the cycle that their parents don't have decent jobs, their parents are on benefits or whatever and they don't see any need to get out of the cycle or indeed any way to get out of the cycle'. Claire positions herself as having the answer to this cycle education - but comments that her pupils don't see things the way she does because 'they don't really realise how education is going to help them [break the cycle], they just see it as like a chore or a bind'. Thus participants drew distinctions between themselves and people like them, and those they saw as other (their pupils), and these distinctions can be understood as expressions of class.

A second way in which participants implicitly positioned themselves as middle-class is through their descriptions of shaping and managing their careers and selves. Miller and Rose (1990) show how personal autonomy, selffulfilment, self-presentation, self-direction and self-management are constructed as beneficial both for individual and for businesses. Individuals are to actively shape and manage their lives to maximise the returns of success and achievement. In the same way, Brown and Hesketh suggest that the self is a key economic resource: "“who you are" matters as much as "what you know" in the market for managerial and professional work' (2004, 35). But Skeggs argues that these constructions of the self are classed. The opportunity for personal expression and development, personal autonomy, self-fulfilment, self-expression and self-actualisation are not open to all. Rather the middle-class 'position of privilege assumes the possibility of self, individualization, reflexivity, choice, mobility and entitlement' $(2004,173)$ that is not open to working-class individuals. The way in which participants talked about Teach First suggested that they were engaged in performing the enterprising self through managing the self as an economic resource as well as searching for personal expression through making a difference. There was an awareness of the significance of whatever job they took for developing the self, learning and being challenged. In the quotation below, Ravi is describing the questions he asked at a recruitment event for Teach First:

It was basically natural graduate questions like: how much are you going to get paid? What's the training programme going to be like? And, you know, what's the whole package? Like how long does it take, what do I get out of it? All the outcomes? And then one interesting thing was about the business leadership programme as well with Teach First so I wanted to know a lot of stuff about that as well. And about placements in schools. Whereabouts it's going to be. And, yeah, how they're going to look after us. (Ravi)

Note here how Ravi describes as 'natural graduate questions' his enquiries about what he will get out of the programme and how he can expect to be looked after. Among the criteria participants had to demonstrate in the application process for Teach First was self-evaluation/critique. Here, one participant at the beginning of the programme describes how she expects to use this in developing the self as she teaches:

I'm very conscious of the need to continue to self-reflect and self-evaluate and I think I'm very conscious of the fact that you have to sort of hold your hand up sometimes and say you know, 'This is going badly, how can I improve it?' and that sort of thing. And I don't, I'm not expecting to go in and do it all right ... [but] I feel pretty confident I think. Although I'm not expecting to get it right straight away. (Focus group participant)

Other participants described how they expected Teach First to help in developing the self: Claire describes how she expects doing Teach First to 'not change my character, but increase my confidence'; Charles describes Teach First as 'the opportunity to make a difference while having the opportunity to develop yourself'; and Brian told us that 'I thought it would be very good personally for my own skills in terms of working with people, time management, organisation'. This expectation of self-development and personal improvement is another indication of the middle-class positioning of these participants. 
Furthermore, there was also an aspiration among participants to find a job that was fulfilling. Participants described looking for employment that was meaningful, challenging and enjoyable. The quotation below is typical:

I wanted an interesting job, and I wanted a challenging job. I didn't want something where I do the job for six weeks and then I keep repeating those six weeks over and over again, because you keep going through essentially the same project. (Brian)

Participants also wanted a job at which they felt they excelled. Several explained that they were considering leaving teaching because while they felt able to teach were not sure if they would be excellent teachers. Participants presented this aspiration for self-fulfilment as quite natural, but, following Skeggs' argument, it can be seen as part of their positioning as middle-class.

I have demonstrated in this section how our interviewees positioned themselves as middle-class, through their descriptions of themselves and other participants, who were seen as 'people like me'; through their descriptions of their schools and pupils, who were positioned as 'other' or 'people unlike me'; and through the way they talked about shaping the self. I now move on to examine the way in which participants made use of different forms of capital in order to access Teach First.

\section{The significance of capital in accessing Teach First}

Employers and government refer to the skills and experiences required by graduates to obtain jobs as employability (Dearing 1997; Yorke 2004; Moreau and Leathwood 2006). Employability is generally understood not only as academic credentials, but as experience, skills, understandings, personal attributes and the way those assets are used and presented (Brown and Hesketh 2004). Employability includes having the 'right' grades from the 'right' institutions, packaging 'soft credentials' in a way that appeals to employers, and using non-academic activities and experiences (e.g. volunteering, employment or travel) to demonstrate managerial competencies such as drive, determination and creative thinking (Brown and Hesketh 2004).

Demonstrating employability requires the possession of cultural and social capital, as Smetherham highlights when she writes that 'constructions of employability are intimately connected to issues of social and personal identity, socialization, personal and cultural capital, habitus, etc.' (2003, n.p.). In Bourdieu's theory of capitals, three kinds of capitals are identified: economic, social and cultural capital (Bourdieu 1986). Economic capital is understood to be command of economic resources, and although not reducible to economic capital, social and cultural capitals are the result of transformations of economic capital. Cultural capital may be embodied in longlasting dispositions of the mind, objectified in the form of cultural goods or institutionalised in educational qualifications, while social capital is the benefits of having a network of relationships and contact which enables access to the capitals of others (Bourdieu 1986). When these capitals are recognised to have value, they act as symbolic capital, a mark of distinction for the possessor. Skeggs (2004) illustrates this by observing that not all cultural resources act as capitals because not all cultural resources are valued in the same way. Blasko (2002) notes that graduates do better in the labour market with good qualifications from compulsory education, after attending prestigious universities and gaining a good class of degree. There are also measurable benefits to graduates from extracurricular activities and overseas study or work (Blasko 2002). Thus these cultural resources (educational qualifications and the skills and dispositions demonstrated by voluntary and extracurricular activities) act as capitals in the graduate labour market. Not all groups have the time, money and dispositions required to develop and acquire these capitals, rather they are concentrated among the upper- and middleclasses (Blasko 2002; Moreau and Leathwood 2006; Heath 2007; Greenbank and Hepworth 2008). Therefore a focus on employability, in particular the soft skills, 'personality package' and extracurricular experiences, limits the competition for graduate jobs to positional conflict among the middle-classes (Brown and Hesketh 2004; Goldthorpe 2006; Redmond 2006). Smetherham (2003) suggests:

[Employability is] about lifestyle issues, values, choices and attitudes, as much as simply about individuals obtaining employment. Employability is not only a matter of making a living or being able to get 'a job', but is also a matter of achieving a 'comfortable' (middle-class) lifestyle.

In this section, I examine the kinds of social and cultural capital that Teach First require in their graduates, and the kinds of capital that participants described using to access Teach First.

Interviewees were asked how they had first heard of Teach First. Most had heard through general sources of information about graduate careers (milkround.com, the university careers service, graduate career publications). Others had heard through friends who thought it might suit them. Questionnaire responses from Cohort 2 showed that $42 \%$ had heard through friends, including a number of Cohort 1 participants. Twenty-six per cent had heard of Teach First from general graduate recruitment information sources (milkround.com, websites, publications, etc.), a further 22\% through their own university careers services or Teach First events held at the university and 7\% through newspaper articles. Many interviewees described first hearing about Teach First through networks of friends and family, and also using these networks to access 'hot knowledge' about Teach First, similar to the ways 
middle-class parents draw on social networks in school choice (Ball and Vincent 1998) and privately educated pupils access information to use in university applications (Reay et al. 2001). One participant talked about her decision to accept a place on Teach First in the context of her friend's decision to turn her place down:

[My friend] did a lot of research before she made that decision, into the business, into whether or not it really was going to be something which would help her get a job at the end of it, and obviously it's a pilot year, you know, it's the first year so no one knows. But she asked everybody she knew, her parents and her uncles and all sorts. (Felicity)

Felicity herself decided to accept the place because 'it fitted all [my] agendas' and she felt 'there's nothing to lose'.

Thus participants described a role for social networks and social capital in accessing 'hot' information to make the decision to apply to Teach First.

Teach First set a number of criteria for applicants. These requirements included the possession of particular forms of social and cultural capital. Institutionalised cultural capital played a part in the assessment of application forms: Teach First staff said that candidates should have a 'good degree' (generally an upper second-class degree), and have studied at a 'good university'. During the period of the evaluation, Teach First concentrated their publicity and graduate recruiters on what they regarded to be the elite, top universities. A member of the Teach First staff commented:

If we had more resources I would go to more universities but I think the people who meet our criteria, $80 \%$ of them will always come from these 10 universities just because that's where many of them seem to be. It's just why many of the top businesses like City Group try only top 10 universities because they know that $80 \%$ of people who they're looking for in the country are at these universities.

Studying at these universities is likely to be preceded by many years of developing cultural and social capital, and also to play a part in developing cultural and social capital.

Application forms and selection day activities were assessed against criteria which include things such as leadership, planning and organisation, problem solving, and resilience, and candidates drew on social and cultural capital in evidencing the criteria. On the selection days observed by the evaluation team, interviewees were required to teach a short lesson and evaluate it with a member of staff and take part in a problem-solving case study. There was also a 'critical behaviour interview' where interviewees were asked about their reasons for applying to the programme, and probed about their ability to work with people from different backgrounds, to take a lead in teams, to resolve difficulties, meet challenges, etc. In their responses, candidates were asked to give examples from recent experience. There were several ways in which participants told us they had drawn on social and cultural capital to demonstrate employability in this process. Firstly, in preparing the lesson, some Teach First applicants were able to draw on the expertise of teachers that they knew, as Charlotte describes below:

My parents helped me a lot ... I did it to them, I basically taught them the lesson, which was quite nice to get a bit of help. (Charlotte)

Others drew on the experiences of people they knew who had been through the scheme:

I was reasonably confident because with [my friend] involved in the scheme I had a good idea of what they wanted, and I felt confident that my experience that I'd had in the past would satisfy what they wanted, so, provided I was able to do the sort of teaching practice bit, the very short thing they did satisfactorily I felt that my sort of background experience meant that I was, pretty much, you know, I was confident that I had what they were looking for really. (David)

In both the application form and the 'critical behaviour interview', candidates were asked to give specific examples which evidenced the criteria. Teach First candidates drew heavily on experiences they had gained from voluntary work, extracurricular activities or experiences during gap years to demonstrate their employability:

I've spent quite a lot of time working with adults with learning disabilities like in this volunteer place in New York ... because the place I worked in New York I was having to work 14 hours a day and it was quite a position of responsibility and I realised that I actually handled it quite well I managed and everything and I thought well maybe I can handle teaching then you know. (Jennifer)

Thus for Jennifer, time, disposition and economic capital were all important in her gaining the volunteering experience which motivated her to apply for Teach First, and that helped her demonstrate her suitability for Teach First.

As in other philanthropic movements, the relatively privileged class position of Teach First participants allows them to portray themselves as having something to offer to alleviate educational disadvantage. Participants talked about wanting to 'give something back', 'do something that would benefit other people' and 'do something to make a difference'. There are parallels with the settlement movement of the late nineteenth century, where men and women from universities and other privileged backgrounds came to live among the poor in an attempt to reduce the inequalities of life (Gilchrist and Jeffs 2001) and which was described by one historian as restricted to 
members of the upper class (Freeman 2002). Only those with something to give are in a position to exercise philanthropy, and in the same way, only those from certain social backgrounds with certain kinds of capital were able to undertake Teach First. In particular, candidates had to demonstrate employability. They used social capital to access advice about the interview process, institutional cultural capital in the form of educational achievements and the cultural capital gained from extracurricular experiences to prove their employability and evidence the Teach First criteria. I now move on to examine the processes of middle-class reproduction that occurred on Teach First, looking first at the reproduction of capital.

\section{The reproduction of capital during Teach First}

Participants entered Teach First with cultural and social capital; once on the programme they were able to accumulate social, cultural and symbolic capital. Teach First marketing stressed the ways in which the Teach First experience would make participants more employable:

Top recruiters look for graduates not just with raw talent, but also a track record of making things happen. Through Teach First, you will gain leadership, communication and influencing skills that are often difficult to build as a junior or graduate recruit in a large organisation. (Teach First website)

The 'challenging school', the short-training period/two-year commitment and Teach First's corporate sponsors are all presented as ways in which participants will develop employability. The 'challenging school' is described as an excellent opportunity to develop skills needed for any career:

Working in a challenging school also means being able to draw upon the insights and advice of more experienced staff, as well as parents, governors and senior managers. By doing Teach First you will learn how to lead through your ability to humbly empathise and deal with stakeholders at every level. (Teach First website)

The short-training period is portrayed as a demonstration of participants' ability to handle pressure and challenge and to learn quickly, as this participant suggests: When you explain teaching [to someone who doesn't know about Teach First] you kind of want to say 'I only got six weeks worth of training and I started teaching on day one and that was it, it was like real fly or die stuff'. (Vimala)

Teach First also provided a number of business-related ttaining and events including: Foundations of Leadership (a leadership development programme), careers fairs, coaching (one-to-one meetings with a business coach to 'consider your career opportunities beyond Teach First, deal with challenges in the work place, establish new contacts and consider new ideas or ways of thinking' [Teach First website]), networking events (e.g. 'cock-up clubs' - meetings with successful leaders speaking about 'their own career low points and how failure and despair can be turned around' [Teach First website]) and internships (Questionnaire data suggested that just under half of Cohort 1 undertook an internship with an employer other than their school in the summer of their first year. The Teach First website suggests that in 2007, 65\% of participants elected to take up a project, work-shadowing or internship opportunity).

At the end of their two years on Teach First, many participants believed that they were more employable. Interviewees suggested a variety of skills that they had gained through Teach First: being client-focussed, time management, problem solving, presentation skills, leadership, public speaking, listening, evaluation, confidence, interpersonal skills, organisational skills and so on. This can be understood as a process of accumulating social, cultural and symbolic capital.

Social capital was accumulated as participants had opportunities make links through their business coach, at networking events, careers fairs and through internships. Of the Cohort 1 participants who responded to our final questionnaire and had gained a job outside teaching, more than three quarters indicated that the advice of their business coach had been a factor contributing to their future career. Questionnaire respondents who had completed an internship saw the major benefit as experiencing a different work environment, and one-third saw a major benefit as making useful connections. One interviewee explained how his job had come about as a direct result of attending a Teach First event:

And I was very fortunate in that one of the Teach First’s Saturday morning lectures was given by a chap from [firm]. Anyway this guy was giving a talk on [area] and that's just the area I always wanted to get into, even before Teach First. And I went and spoke to him afterwards and said I was very much interested in his line of work and [asked] would he have a look at my $\mathrm{CV}$ which is on-line and get back to me if there's any vacancy in his team. And so he did within the week and he said there were actually three people who had seen my CV and were now interested in interviewing me, could I go along for an interview. And so I did and before long, yeah I was offered a job. (Guy)

This illustrates how participants accumulated social capital through their Teach First experience. They also gained cultural capital in the form of a range of experiences. These included transferable skills that participants described acquiring through their teaching:

I think it's giving us as graduates an excellent foundation for a future career in just about anything really because I think if you can stick at teaching for two years in the environments that we're teaching in you're going to be able to turn your mind to 
anything. I think there are indeed a number of transferable skills that we're picking up and ... I just hope that future employers will see that and will see that ... what we've done isn't just teaching, that everything has been urgent, everything has been a challenge, everything has been quick, there’s been rapid progression. (Guy)

But I think I mean I do feel that I am lot better prepared to do a specialised job because I think I mean I have really been ... I feel like I have survived here so far and so I feel a lot more confident about going to other situations you know where there are deadlines and things going on. Also I think I have grown personally as well in that I am .... I am more hardened to challenges, you know, and so I feel I have gained from that sort of experience. (Christopher)

Note here how Guy and Christoper allude to the challenging school and the two-year commitment to enhance their claims to have developed transferable skills. Guy argues that 'if you can stick at teaching for two years in the environments that we've been teaching in [i.e. challenging schools] you're doing to be able to turn your mind to anything', while Christopher feels he is better prepared because he has 'survived here [the challenging school]' where he has become 'more hardened to challenges'. Of the Cohort 1 questionnaire respondents who had already found employment outside teaching in Summer 2006, three quarters believed that their employer had been impressed by the Teach First experiences in their CV and the same proportion had used Teach First experience in the interview process. Participants also identified skills that they had gained through Foundations of Leadership such as developing and executing a business plan (participants had worked on a business plan to enhance pupil performance or confidence by using the support of industry and the school staff. These business plans had been entered into an internal Teach First competition, and the winners had been given the resources to implement the project). Participants had also gained cultural capital in the form of careers knowledge and skills. One interviewee who had a traineeship in a bank said that he would not even have thought of banking before he joined Teach First, and that even if he had applied at that stage he would not have got the job because he had no idea how to make a successful application.

Thus participants developed social and cultural capital as a result of their participation in Teach First. Teach First also provided some participants with symbolic capital, proof of their commitment to 'making a difference'. Several Teach First participants hoped to use their experience in education to get jobs in the education sector:

I will either try to use this educational background to try and get into educational policy of some sort, either domestically or on a kind of international level and so an international development level. (Andrew)

Others argued that first-hand experience of challenging schools motivated them and made them better placed to go into politics or educational management. The use of philanthropic work to enter and colonise a sphere is not a new phenomenon. In Victorian England, the informal charitable visiting of 'gentlewomen' gave rise to middle-class visiting societies and then to social workers and health visitors, while the unpaid work of surgeons in voluntary hospitals provided them with knowledge, power and experience which allowed them to turn themselves into a medical elite (Taylor 2005). Taylor argues that 'the projects of professional closure embarked on by various middle-class occupational groups built on the symbolic and cultural capital they acquired through philanthropic work' (124). Gilchrist and Jeffs (2001) record the criticism of Lansbury that the settlement houses allowed the sons and daughters of the better-off to become experts on social affairs and so gain government jobs and note that many of the key players in the creation of the welfare state spent time in the settlement houses. A similar process of accumulating the symbolic capital necessary to enter social and philanthropic work was beginning in Teach First.

As for other graduates, employability for Teach First graduates was not only about gaining employment but also creating a middle-class lifestyle (Brown, Hesketh and Williams 2003; Smetherham 2003). Through Teach First, participants gained capitals which enabled them to have the kind of lifestyle they hoped for. In year after Teach First, a majority of Cohort 1 participants continued teaching or working in education, while a quarter went into jobs in city and finance, government, policy and non-profit or industry and technology. Almost all those with employment had jobs that would be classified as Social Class 1 by the National Statistics Socio-economic Classifications (and those who did not anticipated moving to this kind of job). Teach First facilitated the (re)production of middle-class privilege through the deployment of social and cultural capital to gain employment. This employment allowed the accumulation of cultural, social, economic and symbolic capital, and so led to a “"comfortable” (middle class) lifestyle' (Smetherham 2003, 13). I now turn to look at the way in which discourses in Teach First tended to reinforce the participants' middle-class values.

\section{The reproduction of middle-class values in Teach First}

At the time of the evaluation, the Teach First website carried a number of highly emotive descriptions of Teach First schools and pupils. It described pupils living in circumstances that made their education particularly challenging; pupils who were struggling to fulfil their potential, who carried the weight of emotion and were scarred by their experiences; pupils who had little comprehension of the value of education and saw school as an extension of a system that has so far failed them. Pupils were described as looking to Teach First participants for guidance and hope. The passages invoked considerable sympathy for these pupils, and one participant told us she 
had been moved to tears by a passage she had seen on the website. The words used to describe pupils and their situations were predominantly negative: 'struggling', 'scarred', 'failed'. There was also an implicit contrasting of the values of university-educated middle-class Teach First participants (assumed to understand the value of education) with their pupils (described as having 'little comprehension of the value of education'). This seemed to imply that the Teach First participant would provide 'guidance and hope' to their pupils through imparting their middle-class values.

Similar themes emerged in interview. Several Teach First participants alluded to feelings of unease and anger about the (class) inequalities they encountered in schools. Participants described themselves as shocked and horrified by some of the situations they encountered in schools:

I was quite a sheltered middle-class girl ... Some of the problems these kids have blows your mind and some of them actually come through and they leave it all behind and they go home and what they have to deal with, and it humbles you, it really, really humbles you. (Jaya)

Many told us how upset and angry they felt about the situations they witnessed:

It makes me so mad that children in this country don't have the same access to education just because of where they are born and where their catchment area is, or whatever it is, that they just don't have access to a good school, they have to deal with problems that other people don't. I have got two schools in [area] that I am [working with] at the moment literally about a 15minute walk away. They are both state schools but just at completely opposite ends of the spectrum and I don't get it, like, I just don’t understand how that can be. (Vimala)

Also I think ... I don’t see why if people are better off why they should get the best teachers; I don't see why you should. And like not everyone can afford to send their children to private school or to move to an area where there are good schools so I think that's an unfair thing about our society. (Ebun)

For these participants, exposure to some of the (class) inequalities in British society made them feel uncomfortable and angry, and this kind of reaction again has parallels with nineteenth century philanthropists and those involved in the settlement houses (Gilchrist and Jeffs 2001). Sayer argues that lay discussions of class are highly charged and generates feelings of unease and ambivalence, arguing that 'embarrassment, and indeed shame, are appropriate responses to the immorality of class' $(2002,9.5)$.

However, class is also a site of moral judgements. Sayer writes that 'moral stigma is frequently attached to those who are worst off in class terms, and correspondingly, a moral privilege is attached to high class' $(2002,4.10)$. Some participants began to make moral judgements about the behaviour of pupils, and particularly about the behaviour of pupils' parents:

You know, if the parents are shouting and swearing and resorting to hitting and violence and abuse and getting angry to deal with things then that's a very challenging school. When you've got parents who think it's more important to go down to the look after their kids or get their kids to do homework or it's more important for them to go shopping or to mess about than to, you know, whatever, than it is for their kids to experience a more wholesome upbringing then yeah, that's where you're going to find difficulties in schools. (Guy)

Here Guy is contrasting the behaviour of parents who allow children to go shopping or mess around, with 'wholesome' parenting (looking after kids and getting kids to do homework), making clear moral judgements about the behaviour of parents at his school. Other participants compared their life experiences with those of their pupils:

And that is the thing I have noticed with young people and especially young people I have taught is that they have such screwed up home lives a lot of them and I feel very lucky that when I came home from school, my mum was there as a housewife. I came home, you know, we were the sort of family that all ate dinner together at a table and things like that. And a lot of young people today don't have that because of their parents working and stuff. (Vimala)

Again we see a moral stigma attached to the 'screwed up home lives' of her pupils and moral privilege to 'the sort of family that all ate dinner together at a table', although Vimala does try indicate that parents are not to blame for 'screwed up home lives' because of the pressure on them to work. Interviewees frequently referred to the difference between their own experience of parental support and that of their pupils:

[A] lot of the girls are from backgrounds where maybe the parents don't always value education. I know my parents, when I was at school, they were very supportive and I think sometimes it is not like that. (Christopher)

The parents of the school I went to, the parents were all very supportive of the school as such and played a much more active role in the school. It was a very small school I went to so it was possible to do that and this, on the other hand, is a very large school so getting involved in that way, having a significant number of parents involved in stuff makes it more difficult because of the sheer scale of the operations. (Kalidas)

These participants are attaching some moral privilege to the educational support they received, and some moral stigma to unsupportive parents, although again, Kalidas is sympathetic as to why parents might be less involved (because the school is so large and the 'sheer scale of the operations' makes it difficult). However, throughout the 
talk of participants there was an assumption that their experiences of a 'wholesome upbringing', and supportive, aspirational parents represented an ideal, morally superior childhood.

Sayer describes how working-class parents sometimes question their (workingclass) parenting practices under the middle-class gaze with 'justified suspicion that some [middle-class] values, behaviours, goods are actually not worth having, but merely required by dominant norms' (2002, 7.14 emphasis in original). Although participants described shock at the situations they encountered, there was little evidence that this 'shock' led middle-class Teach First participants to question their values or behaviours. Rather this exposure tended to reinforce their beliefs in middleclass values. There was no hint that Teach First participants might be able to learn from their working-class other. In the next section, I will argue that this lack of questioning was because the discourses of natural ability and educational-based meritocracy used in marketing Teach First and adopted by participants obscured the role of middle-class privilege on the educational achievements and career trajectories of participants, and led them to see their achievements as deserved and inevitable.

\section{The reproduction of discourses justifying middle-class power and privilege}

The Teach First website describes participants as talented, able, exceptional, outstanding top graduates, from the best universities, with excellent qualifications, who have ideas, ambition, superb communication skills and a genuine desire to make things happen. A member of Teach First staff explained that Teach First is about selecting 'academically gifted' graduates who will be 'naturally excellent teachers ... they just naturally have some innate ability to be great teachers'. This language presents the success of Teach First participants as natural and inevitable - they are 'naturally excellent teachers' with 'innate ability' and outstanding personal qualities. The recruitment process is presented as an objective procedure that identifies the best graduates to participate in Teach First:

Teach First runs assessment days which have been developed with its employer partners and education specialists to select outstanding graduates. The selection criteria are among the most rigorous of any employer, and ensure that Teach First participants have the energy, commitment and ability to communicate required to succeed in secondary classrooms, as well as the potential to become outstanding leaders in any field. (Teach First website)

Thus selection criteria will 'ensure' Teach First participants have the potential to become 'outstanding leaders in any field'. It was stressed to us by Teach First staff that 'the whole part of the ethos was selecting the right people'. Throughout Teach First publicity, access to Teach First is presented as an competition between applicants to prove who is 'best' - the kind of meritocracy referred to by Tony Blair (Wheen 2001), where it is solely 'natural ability' that counts. There is no hint in the publicity that class position might be significant, although Goldthorpe (2006) argues that an educational-based meritocracy in Britain is a myth, and I have demonstrated that social and cultural capital were key to participants gaining a place. In fact access to Teach First resembled more closely the kind of meritocracy originally written about in Young's satire - that is, a situation where the elite believe themselves to have been selected based on intelligence, but in fact have the power and the means to reproduce themselves, creating a disconnection between the elite and the masses (Young 1958). Although several interviewees reflected on how lucky they felt to have attended a particular school or university, there was little reflection on the structural factors which had enabled them to do this (e.g. access to high-achieving schools because of parental economic or cultural capital), or the parallel consequences of structural lack of opportunity for working-class children. Rather there was an acceptance that it was their 'natural ability' that had helped them attain their current position. Thus the language of 'natural ability' obscured the middle-class privilege that Teach First graduates had experienced.

\section{Conclusions}

I have argued that Teach First is a site for the reproduction of middle-class privilege through the accumulation of capital, the reinforcing of middle-class values and views of the working-class other, and the production of discourses obscuring middle-class privilege and power. The decision to teach with Teach First has a number of parallels with the choice by white middle-class parents of urban comprehensive schooling for their children (Reay et al. 2008). Although both practices are underpinned by some commitment to public welfare and the common good, both also contain elements of self-interest, and lead to the accumulation of cultural capital through exposure to difference and challenge (Reay et al. 2007). Participation in Teach First is not enough to dissolve difference and hierarchy, but most often results in the reinforcing of middle-class values, a situation that again has close parallels with the middle-class choice to send a child to an urban comprehensive. As Sayer suggests 'Even actions that which are not driven by struggle for advantage over others, indeed, even those that have egalitarian motives, are likely to be twisted by the field of class forces in ways which reproduce class hierarchy' $(2005,169)$.

Do these conclusions have wider significance? After all, Teach First is a small scheme, and trains only a tiny percentage of all teachers in England. However, although small, the scheme has been given considerable attention by policy analysts and policy-makers (e.g. DCSF 2008; Margo et al. 2008), and cited as a force for good in 
education by various politicians including Tony Blair (Teach First 2007). In policy discourses, Teach First is presented as something revolutionary to address educational disadvantage through providing teachers in schools that struggle to recruit them, marketing teaching in these 'challenging schools' as a high-status option and allowing participants to witness the effects of social inequality in Britain. However, I would argue that the role of Teach First in reproducing middle-class privilege and values mean that in the long term, its impact on educational disadvantage will be limited, because it does not tackle the fundamental inequalities in social, cultural and economic capital between classes, the invisibility of middle-class privilege and the discourses of working-class deficit. Any policy that draws on Teach First should acknowledge this.

It may be possible to build on the Teach First model, which successfully appeals to the desire to act ethically and 'make a difference'. In appealing to this desire, I would like to see a recognition of the role of self-interest, and the way middle-class actors accrue greater benefits and value from altruistic choices their class others. In building on the Teach First model, I would want to minimise the reproduction of middle-class privilege and values, through changing the way challenging schools and working-class pupils are conceptualised and described by Teach First. I would also like to see more done to make visible middle-class privilege. Exposing middle-class participants to their class other will not automatically result in awareness of class privilege, but it does provide opportunities to discuss issues such as class, capitals, privilege and structural inequalities. These issues are not easy to discuss, and rethinking values and beliefs would be painful for participants. But perhaps this is how Teach First could make the most significant difference.

\section{Acknowledgements}

My thanks go to everyone at the Institute for Policy Studies in Education at London Metropolitan University who was involved in collecting this data and who supported me in writing this article, in particular Jocelyn Robson and Merryn Hutchings who read and commented on earlier drafts.

\section{Notes}

1. This list of leading employers is compiled by asking more than 15,000 final-year university students which organisations they feel offer the best prospects for graduates based on the training and development on offer, the quality of the employer's recruitment promotions and its overall reputation.

2. During the course of the evaluation, the TTA became the Training and Development Agency, TDA.

3. We administered three questionnaires to the first cohort, and two to the second. The response rates were above $90 \%$ for all questionnaires, except the final questionnaire to the first cohort, where the planned distribution was affected by the London bombing on 7 July, and the response rate was only $51 \%$.

\section{Notes on contributors}

Sarah Smart was a research fellow at the Institute of Policy Studies in Education (IPSE) at London Metropolitan University when she wrote this article. Directed by Professor Merryn Hutchings, Sarah, Dr Uvanney Maylor (IPSE), Dr Heather Mendick (IPSE) and Professor Ian Menter (University of Glasgow) worked on the TTA-funded evaluation of the innovative aspects of Teach First between September 2003 and December 2005, and the Gatsby Trustfunded evaluation of Teach First Plus. The team members have also researched other aspects of teacher training and teacher careers for funders including the General Teaching Council, the Economics and Social Research Council and the Department of Children, Schools and Families. Sarah is currently studying for her $\mathrm{PhD}$ at the University of Reading.

\section{References}

Ball, S.J. 2003. Class strategies and the education market: The middle classes and social advantage. London: RoutledgeFalmer.

Ball, S.J., and C. Vincent. 1998. 'I heard it on the grapevine': 'Hot' knowledge and school choice. British Journal of Sociology 19, no. 3: 377-400.

Ball, S.J., C. Vincent, S. Kemp, and S. Peitakienen. 2004. Middle class fractions, childcare and the 'relational' and 'normative' aspects of class practices. Sociological Review 52, no. 4: 478-502.

Blasko, Z. 2002. Access to what: Analysis of factors determining graduate employability. A report to HEFCE by CHERI. http://www.hefce.ac.uk (accessed December 15, 2008).

Bourdieu, P. 1986. The forms of capital. In Handbook of theory of research for the sociology of education, ed. J.E. Richardson, 241-58. Westport, CT: Greenwood Press.

Brown, P., and A. Hesketh. 2004. The mismanagement of talent: Employability and jobs in the knowledge economy. Oxford: Oxford University Press. 
Brown, P., A. Hesketh, and S. Williams. 2003. Employability in a knowledge-driven economy. Journal of Education and Work 16, no. 2: 107-27.

Dearing, R. 1997. The Dearing Report: National Committee of Inquiry into Higher Education. http://www.leeds.ac.uk/educol/ncihe/ (accessed April 9, 2008).

DCSF. 2008. Being the best for our children: Releasing talent for teaching and learning. London: DCSF.

Freeman, M. 2002. 'No finer school than a settlement': The development of the educational settlement movement. History of Education 31, no. 3: 245-62.

Gilchrist, R., and T. Jeffs. 2001. Introduction. In Settlements, social change and community action: Good neighbours, ed. R. Gilchrist and T. Jeffs, 194-213. London: Jessica Kingsley.

Goldthorpe, J. 2006. Education-based meritocracy: The barriers to its realisations. Paper presented at the DfES Annual Research Conference, November 24, London.

Greenbank, P., and S. Hepworth. 2008. Working class students and the career decisionmaking process: A qualitative study. A PROP report for HESCU. http://www.hecsu.ac.uk/hecsu.rd/research_reports_278.htm (accessed December 15, 2008).

Heath, S. 2007. Widening the gap: Pre-university gap years and the 'economy of experience'. British Journal of Sociology of Education 28, no. 1: 89-103.

Hutchings, M., U. Maylor, H. Mendick, S. Smart, and I. Menter. 2006. An evaluation of innovative approaches to teacher training on the Teach First programme: Final report. London: TDA.

http://www.tda.gov.uk/upload/resources/teach\%20first\%20evaluation\%20report\% 2005-06.doc.

Lawler, S. 2005. Introduction, special issue on class, culture and identity. Sociology 39, no. 5: 797-806.

Margo, J., M. Benton, K. Withers, S. Sondha, and S. Tough. 2008. Those who can? London: IPPR.

Mendick, H., M. Hutchings, and C. Steensborg. 2007. Evaluation of the impact of Teach First plus [Report commissioned by Gatsby Technical Education Projects]. London: IPSE.

Miller, P., and N. Rose. 1990. Governing economic life. Economy and Society 19, no. 1: 1-31.

Moreau, M.-P., and C. Leathwood. 2006. Graduates’ employment and the discourse of employability: A critical analysis. Journal of Education and Work 19, no. 4: 305-24.

Ofsted. 2008. Rising to the challenge: A review of the Teach First initial teacher training programme. London: HMSO.

http://www.ofsted.gov.uk/assets/Internet_Content/Shared_Content/Files/2008/jan/teachfirst_rv.pdf (accessed April 9, 2008).

Pakulski, J., and M. Waters. 1996. The death of class. London: Sage.

Reay, D. 1997. Feminist theory, habitus and social class: Disrupting notions of classlessness. Women's Studies International Forum 20, no. 2: 225-33.

- 1999. 'Class acts': Educational involvement and psycho-sociological class processes. Feminism and Psychology 9 , no. 1: 89-106.

2005. Beyond consciousness? The psychic landscape of social class. Sociology 39, no. 5: 911-28.

2006. The zombie stalking English schools: Social class and educational inequality.

British Journal of Educational Studies 54, no. 3: 288-307.

Reay, D., G. Crozier, D. James, S. Hollingworth, K. Williams, F. Jamieson, and P. Beedell. 2008. Reinvigorating democracy?: White middle class identities and comprehensive schooling. Sociological Review 56, no. 2: 238-55. Reay, D., J. Davies, M. David, and S.J. Ball. 2001. Choices of degree or degrees of choice? Class, 'race' and the higher education choice process. Sociology 35, no. 4: 855-74.

Reay, D., S. Hollingworth, K. Williams, G. Crozier, F. Jamieson, D. James, and P. Beedell. 2007. 'A darker shade of pale’ whiteness, the middle classes and multi-ethnic inner city schooling. Sociology 41, no. 6: 1041-60.

Redmond, P. 2006. Outcasts on the inside: Graduates, employability and widening participation. Tertiary Education and Management 12, no. 2: 119-35.

Sayer, A. 2002. What are you worth?: Why class is an embarrassing subject. Sociological Research Online 7, no. 3.

. 2005. The moral significance of class. Cambridge: Cambridge University Press.

Skeggs, B. 1997a. Classifying practices: Representations, capitals and recognitions. In Class matters, ed. P. Mahoney and C. Zmroczek, 123-40. London: Taylor \& Francis.

1997b. Formations of class and gender: Becoming respectable. London: Sage.

2004. Class, self, culture. London: Routledge.

Smetherham, C. 2003. The employability of first class graduates. Paper presented at the BERA Conference, September 10-13, Heriot-Watt University, Edinburgh. http:// www.leeds.ac.uk/educol/documents/00003352.htm (accessed March 26, 2008). 
Taylor, R. 2005. Rethinking voluntary work. Sociological Review 53, no. 2: 117-35.

Teach First. 2007. Teach for all launches at Clinton Global Initiative Press release.

http://www.teachfirst.org.uk/press/press_releases/270907 (accessed June 17, 2008).

Tomlinson, M.B. 2008. 'The degree is not enough': Students’ perception of the role of higher education credentials for graduate work and employability. British Journal of Sociology of Education 29, no. 1: 49-61.

Walkerdine, V., H. Lucey, and J. Melody. 2001. Growing up girl: Psychosocial explorations of gender and class. Basingstoke: Palgrave.

Wheen, F. 2001. Satirical fiction is becoming Blair’s reality. Guardian. February 14, Editorial.

Yorke, M. 2004. Employability in higher education: What it is, what it is not. LTSN Generic

Centre: ESECT. http://www.adm.heacademy.ac.uk/resources/resources-by-topic/employability/employability-resources-andpublications (accessed June 17, 2008).

Young, M. 1958. Rise of the meritocracy 1870-2033: An essay on education and equality. London: Thames \& Hudson. 